Article received 27.02.2018 $p$.

Article accepted 29.03.2018 p.

\title{
ВПЛИВ МЕТОДУ СТВОРЕННЯ НАСАДЖЕНЬ ДУБА ЗВИЧАЙНОГО (QUERCUS ROBUR L.) НА ÏХНЮ ПРОДУКТИВНІСТЬ В УМОВАХ СВІЖОЇ ГРАБОВОЇ ДІБРОВИ ПРАВОБЕРЕЖНОГО ЛІСОСТЕПУ УКРАЇНИ
}

\begin{abstract}
Досліджено продуктивність штучних дубових насаджень свіжих грабових дібров залежно від методу їхнього створення. За даними пробних площ у віці 10-68 років визначено основні лісівничо-таксаційні показники культур дуба звичайного $(Q u-$ ercus robur L.). Виявлено їхню залежність від методу створення і відмінність у продуктивності культур, які створені садінням сіянців і висівом жолудів на свіжих зрубах. Встановлено, що, починаючи з 10-річного віку, середні висоти культур дуба істотно залежать від методу створення культур. Висоти культур дуба, створеного висівом жолудів, у віці молодняка на 6$9 \%$ більші, ніж за умови створення культур садінням сіянців. 3 часом ця різниця за висотами збільшується і в VII класі становить 11-19\%. Оцінено вплив методу створення на середні діаметри дерев дуба. Доведено, що до 40 років середній діаметр дерев дуба більший за умови створення насадження садінням, але з часом діаметри вирівнюються. Виявлено певну послідовність у збереженні чисельності дуба. За умови висівання кількість збережених дерев на 1 га в 10-річному віці на $37,5 \%$ більша, але з часом різниця зменшується і в 68 років становить 17,3\%. Встановлено вплив методу створення на запас дерев дуба. За умови створення культур висівом, залежно від віку насадження, запас дерев дуба на 1 га збільшується в середньому до $40 \%$. Встановлено вплив методу створення культур на загальну продуктивність змішаних дубових деревостанів. З'ясовано, що за умови створення культур методом висіву жолудів, запаси насаджень на 1 га більші в середньому на 17 \%. Культури дуба, створені висівом, мають краще очищення стовбурів від гілля і сучків, а стовбури є більш повнодеревними.
\end{abstract}

Ключові слова: культури дуба; склад насадження; таксаційні показники; висів жолудів; садіння сіянців.

Вступ. Метод створення штучних насаджень залежить від типу лісорослинних умов, біологічних особливостей деревних і кущових видів рослин, стану лісокультурної площі та низки інших чинників.

Ефективність створення культур висівом залежить, передусім, від оптимального поєднання екологічних факторів - тепла, вологи та аерації грунту, терміну та норм висіву, глибини та способів висівання насіння, а також ретельності доглядів за грунтом і сходами (Yurkevich, 1960; Hordiienko et al., 1999; Bondar \& Hordiienko, 2006). Після появи сходів важлива наявність двох екологічних факторів - світла і поживних речовин у rрунті (West, 2006). Забезпечення зазначених факторів $\epsilon$ складним завданням. Культури, які створені висіванням, у перші роки життя погано витримують несприятливі погодно-кліматичні умови, потерпають від конкуренції трав'яної рослинності, а тому потребують довгот- ривалого й ретельного догляду (Soldatov, 1961; Borchert \& Tyler, 2010; Maiboroda, 2010). Метод висіву відповідає самій природі лісовідтворення - ліс, що створений висіванням, довговічніший, ніж той, що створений садінням (Clark \& Schweitzerb, 2016; Dey \& Kabrick, 2016; Dey, Kabrick \& Schweitzer, 2017). Насамперед, це пояснюють відсутністю деформації кореневої системи та інших пошкоджень сіянців, які неминуче виникають під час викопування, транспортування та садіння. Так, Г. Ф. Морозов (Morozov, 1950) зазначив, що, передусім, успіх висіву залежить від того, чи відповідає цей метод культури лісу типу лісорослинних умов, способу висіву, обробітку грунту, часу висівання, якості насіння тощо. Під час висівання жолудів на постійне місце автори (Lositskiy, 1963; Lohhinov, 1968; Tihonov, 1970) констатували, що молоді дубки у стадії сходів та однорічних сіянців краще пристосовуються до умов середовища та

\section{Інформація про авторів:}

Остапчук Олександр Степанович, канд. с.-г. наук, доцент, доцент кафедри лісового господарства. Email: ostapchyk1958@gmail.com

Кузевич Василь Степанович, канд. с.-г. наук, доцент, завідувач кафедри лісового і садово-паркового господарства. Email: vasyl.kuzovych@gmail.com

Соваков Олександр Вікторович, канд. с.-г. наук, доцент, доцент кафедри відтворення лісів та лісових меліорацій. Email: sovakov_o@ukr.net

Цитування за ДСтУ: Остапчук О. С., Кузьович В. С., Соваков О. В. Вплив методу створення насаджень дуба звичайного (Quercus Robur L.) на їхню продуктивність в умовах свіжої грабової діброви правобережного лісостепу України. Науковий вісник НЛтУ України. 2018, т. 28, № 2. С. 59-63.

Citation APA: Ostapchuk, O. S., Kuzovych, V. S., \& Sovakov, O. V. (2018). Influence of the Method of Oak (Quercus Robur L.) Stands Formation on their Productivity Under the Conditions of Hornbeam-Oak Forest in the Forest-Steppe Zone of Right-Bank Ukraine. Scientific Bulletin of UNFU, 28(2), 59-63. https://doi.org/10.15421/40280210 
є продуктивнішими, ніж сіянці, що вирощені у розсаднику і пересаджені у віці декількох років на лісокультурну площу. На думку К. Б. Лосицького, за наявності жолудів у відповідних лісорослинних умовах перевагу потрібно надавати виключно висіванню. М. І. Гордієнко зазначав, що за умов створення культур дуба з обмеженою кількістю атмосферних опадів, доцільно віддавати перевагу висіванню жолудів на постійне місце. За умови способу створення лісових культур можна сформувати біологічно стійкі насадження.

Садіння лісу має певні переваги над висівом, серед яких 5-7-кратне скорочення витрат насіння, сіянці майже не пошкоджують гризуни і птахи, забезпечується їхнє рівномірне розміщення, вони меншою мірою пригнічуються трав'яною рослинністю та поростю інших видів деревних рослин, зменшується кількість доглядів за культурами та скорочується термін їхнього зімкнення (Hordiienko, 1999; Bondar \& Hordiienko, 2006). Водночас, насадження, що створені садінням, змикаються пізніше, ніж створені висівом, повільніше і гірше очищуються від сучків, дають менш повнодеревні стовбури, а деревина дуже часто має гіршу технічну якість (Rudnev \& Ryibachok, 1975; Thompson, 2017). Культури дуба, створені садінням, ослаблені ще й тому, що після пересаджування з розсадника сильно пошкоджується стрижневий корінь, який інтенсивно формується у перші роки. Як наслідок, коренева система стає більш поверхневою, а дубові деревостани - менш стійкими (Yurkevich, 1960; Hordiienko et al., 1999). На думку Г. Ф. Морозова, ні садіння, ні висів не $є$ універсальними способами створення лісу, потрібно користуватися ними обома залежно від багатьох обставин, головними 3 яких є тип лісорослинних умов, вид та економічна доцільність (Morozov, 1950).

Метод створення має відповідний вплив на продуктивність майбутніх насаджень (Krinard \& Johnson, 1988; Brudvig \& Asbjornsen, 2007). На цей час в науковому колі лісівників існують різні погляди щодо створення культур дуба звичайного, особливо чистих культур у різноманітних лісорослинних умовах України. Тема методу створення культур залишається дискусійною.

Мета дослідження - визначення продуктивності штучних дубових насаджень свіжих грабових дібров, які створені різними методами. Завдання дослідження полягало у закладанні низки пробних площ з визначенням лісівничо-таксаційних показників різновікових культур дуба звичайного у віці 10-68 років, створених методом садіння сіянців і висіву жолудів на свіжих зрубах. Залежно від методу створення необхідно було провести лісівничо-таксаційну характеристику дубових деревостанів, зробити відповідні висновки і подати рекомендації.

Матеріал і методи дослідження. Дослідження культур дуба звичайного проведено в умовах свіжих грабових дібров ДП "Уманське лісове господарство" і ДП "Звенигородське лісове господарство". Було закладено 32 тимчасові пробні площі (далі - ТПП). Грунт сірий лісовий середньо-суглинковий свіжий. Схема розміщення садивних місць - 4,0×0,6 $(0,7)$ м і $6,0 \times 0,6(0,7)$ м. Схема розміщення посівних місць $-4,0 \times 0,4(0,5)$ м і $6,0 \times 0,4(0,5)$ м. Для визначення методу створення насаджень використано "Книгу обліку лісових культур" низки лісництв Уманського і Звенигородського лісових господарств. У книгах обліку лісових культур наявна інформація, починаючи з 1948 р. Під час дослідження проводили загальний камеральний відбір лісових культур і їхнє обстеження в натурі. ТПП відбирали згідно 3 загальноприйнятими у лісовій таксації та лісівництві методиками, таксаційні показники насаджень визначали на основі нормативно-довідникових матеріалів для таксації лісів України і Молдавії (Shvidenko et al., 1987). Для отримання об'єктивних таксаційних і лісівничих показників насаджень, вивчення динаміки їхнього росту та розвитку на кожній ТПП брали не менше 200 дерев головної породи, розміри якої встановлювали 3 цього ж розрахунку. Висоти дерев вимірювали за допомогою екліметра-висотоміра. Таксацію деревостанів проводили за ярусами, а в різновікових насадженнях за поколіннями. Клас бонітету визначали за середнім віком і середньою висотою основного елемента лісу. Відносну повноту кожної складової визначали за даними площ поперечних перерізів і таблиць ходу росту (Hrom, 2002).

Результати дослідження. У віці 10 років дубові насадження повністю сформовані. У культурах, створених 3 розміщенням садивних місць $6,0 \times 0,6$ м, проведено смуговий обробіток грунту культиватором КЛБ- 1,7 . Культури дуба на ТПП 7 створено висівом жолудів. За умови складу насадження 9Дз1Гз+Яз воно має такі таксаційні показники: середня висота - 3,6 м, середній діаметр - 6,6 cм, запас - $11 \mathrm{~m}^{3} \cdot \mathrm{ra}^{-1}$ і збереженість 2446 шт. га $^{-1}$ дерев дуба. Відносна повнота - 0,46, клас бонітету $-\mathrm{I}^{\mathrm{b}}$. Культури на ТПП 8 створено садінням однорічок дуба. На цей час склад насадження такий: 7Дз2Яз1Гз+Клг, Брс. Таксаційні показники такі: середня висота $-5,1$ м, середній діаметр - 7,2 см, запас $13 \mathrm{~m}^{3} \cdot \mathrm{ra}^{-1}$, відносна повнота - 0,48, клас бонітету насадження - $\mathrm{I}^{\mathrm{b}}$. У даному насадженні збереглося 1504 шт. га $^{-1}$ дерев дуба, що на 942 дерева менше.

За однакової агротехніки обробітку грунту в культурах віком 13-15 років, створених висівом (ТПП 9), дерева дуба мають середню висоту 10,0 м, а створених садінням (ТПП 45, ТПП 46) - 7,3-7,4 м, що менше на $14 \%$. Клас бонітету насаджень $-\mathrm{I}^{\mathrm{b}}$, розходження в середніх діаметрах відсутні. У культурах, що створені висівом, збереглося 1601 шт. га $^{-1}$ дерев дуба, що на 1002 дерева більше, ніж на ТПП 45.

Аналізуючи насадження дуба у віці 21-22 роки, що створені на розкорчованих смугах корчувачем ДП-8А висівом жолудя на них (ТПП 11, ТПП 12) та садінням дуба на таких же смугах (ТПП 13), продовжуємо спостерігати відмінність таксаційних показників. На цей час культури дуба на ТПП 11 і ТПП 12 мають такі таксаційні показники: середня висота - 13,5-13,6 м; середній діаметр - 9,5-9,6 см; запас дерев дуба - 50-55 м ${ }^{3} \cdot \mathrm{ra}^{-1}$; повнота - 0,78-0,80; клас бонітету насадження $-\mathrm{I}^{\mathrm{b}}$. Збережено 1047-888 шт. га $^{-1}$ дерев дуба. За умови садіння культур (ТПП 13) середні показники такі: висота 13,1 м; діаметр - 10,0 см; клас бонітету - $\mathrm{I}^{\mathrm{b}}$; повнота 0,77. За збереженості 497 шт. га $^{-1}$ дерев дуба, його запас становить $27 \mathrm{~m}^{3} \cdot \mathrm{ra}^{-1}$, що в середньому на $48 \%$ менше. Так, склад насадження становить 4Дз4Гз1Яз1Клг+Брс і потребує термінового поліпшення використовуючи рубки догляду.

Порівнюючи 28-30-річні культури на ТПП 17 і ТПП 66 , які створені висівом жолудів, і культури на ТПП 15 , ТПП 16, ТПП 18, ТПП 19 і ТПП 32, які створені садінням, доцільно вказати на подальшу відмінність у продуктивності між цими насадженнями. Насадження, що створені висівом, мають середню висоту 14,2-15,8 м, а 
створені садінням - 13,7-14,5 м, що в середньому на 0,9 м менше. Середні діаметри культур, які створені висівом, знаходяться в межах 10,1-13,1 м, а створені садінням, мають середній діаметр 12,4-13,9 см. За бонітетом і повнотою розбіжностей немає. Треба зазначити, що за умови висівання жолудів у середньому збереглося 708, а садіння дуба - 526 шт. га $^{-1}$, що на $25,1 \%$ менше. У загальному запасі значних розбіжностей не виявлено. Встановлено вагому різницю за запасом дуба. Так, насадження, що створені висівом, мають в середньому запас дуба 54 , а садінням $-43 \mathrm{~m}^{3} \cdot \mathrm{ra}^{-1}$, що на $11 \mathrm{~m}^{3} \cdot \mathrm{ra}^{-1}(20,3 \%)$ менше.

Проаналізовано культури віком 48-50 років. Насадження, які створені висівом на ТПП 22, ТПП 24, ТПП 25 і ТПП 26, мають середню висоту 20,7-24,3 м, а культури на ТПП 21, ТПП 23, які створені садінням, мають висоту 19,8-20,5 м, що в середньому на 2,1 м (9,4\%) менше. Щодо середніх діаметрів, то істотних розходжень між ними не виявлено. Вони знаходяться в межах 20,5-24,2 см. У насадженнях, які створені висівом, виявлено в середньому 1107 шт. га $^{-1}$, а за садіння сіянцями - 896 дерев, що на 211 дерев (19,1\%) менше. Встановлено, що запас дуба за висіву знаходиться в межах 139-182, а за садіння - 109-113 $\mathrm{m}^{3} \cdot \mathrm{ra}^{-1}$, що в середньому на $43 \mathrm{~m}^{3} \cdot \mathrm{ra}^{-1}(28,5 \%)$ менше.

У насадженнях віком 56-57 років спостерігається подальша розбіжність у таксаційних показниках насаджень. Так, на ТПП 27 і ТПП 29 за умови створення культур висівом, середня висота знаходиться в межах 24,5-25,5 м, а на ТПП 28 і ТПП 34 за умови садіння сіянців дуба - в межах 21,9-22,6 м, що в середньому на 2,4 м (9,6 \%) менше. У величинах середніх діаметрів істотних розбіжностей не виявлено, вони знаходяться в межах 25,4-25,5 см. Класи бонітету, повноти і поточні прирости розбіжностей не мають. Встановлено відмінність у кількості збережених дерев дуба. За умови висівання збережено 273-408, а за садіння - 210-354 шт. га 1 , що в середньому на 59 дерев (17,3\%) менше. Відповідно, запаси збережених дерев дуба також відрізняються. За умови створення насаджень висівом запас дуба знаходиться в межах 176-245 $\mathrm{m}^{3} \cdot \mathrm{ra}^{-1}$, а за створення лісових культур садінням - 114-127 $\mathrm{m}^{3} \cdot \mathrm{ra}^{-1}$.

Встановлено, що в 67-68-річних штучних дубових насаджень продовжується тенденція до збільшення розбіжності в середніх висотах, діаметрах, запасах та збереженості головної породи. Подальші дослідження за віком і методом створення в насадженнях старшого віку не проводили, оскільки в лісництвах документацію зі створення й обліку лісових культур ведуть тільки з 1948 р.

Результати дослідження зміни висоти дерев дуба 3 віком, залежно від методу створення, підтверджуються логарифмічною залежністю між ними (рис. 1) і відображаються такими формулами:

$$
\begin{gathered}
y=11,453 \operatorname{Ln}(x)-22,043 ; \\
y=9,9291 \operatorname{Ln}(x)-17,9,
\end{gathered}
$$

де: $y$ - середня висота, м; $x$ - вік насадження, років.

Аналізуючи рис. 1, помітно, що в насадженнях, які створені висівом жолудів, культури дуба у всіх класах віку мають більшу висоту. Виявлено, що дерева дуба більше очищені від сучків і гілля, мають більш повнодеревні стовбури. За літературними даними (Bondar \& Hordiienko, 2006) відомо, що максимальний ріст дуба в висоту відбувається до 80-90-річного віку. Після цього віку метод створення насаджень менше впливає на їхню висоту. У віці 100-120 років приріст у висоту знижується, а після 120 років закінчується взагалі.

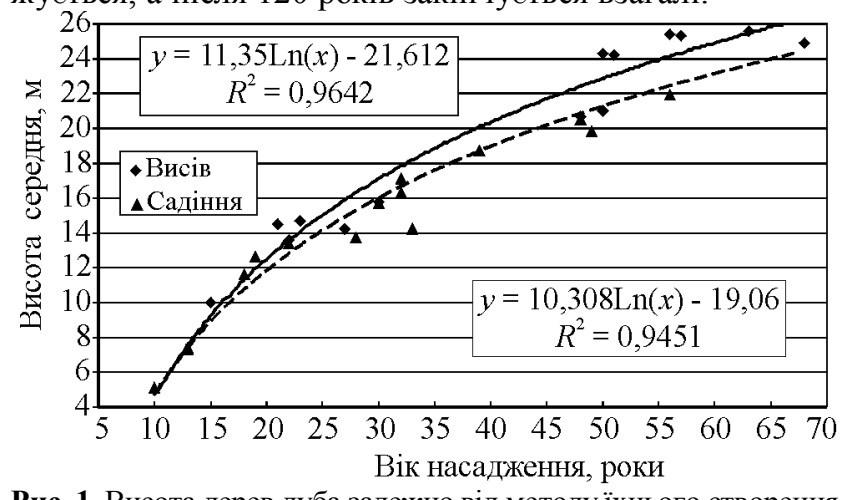

Рис. 1. Висота дерев дуба залежно від методу їхнього створення

Зміна середнього діаметра дубових насаджень 3 віком залежно від методу їхнього створення (формула (3) i (4), рис. 2), дає підстави стверджувати, що в дубових насадженнях у віці 10-68 років істотної відмінності за діаметром не виявлено, а метод створення не впливає на цей таксаційний показник:

$$
\begin{aligned}
& y=13,01 \operatorname{Ln}(x)-29,298 \\
& y=12,045 \operatorname{Ln}(x)-25,364
\end{aligned}
$$

де: $y$ - середній діаметр, см; $x$ - вік насадження, років.

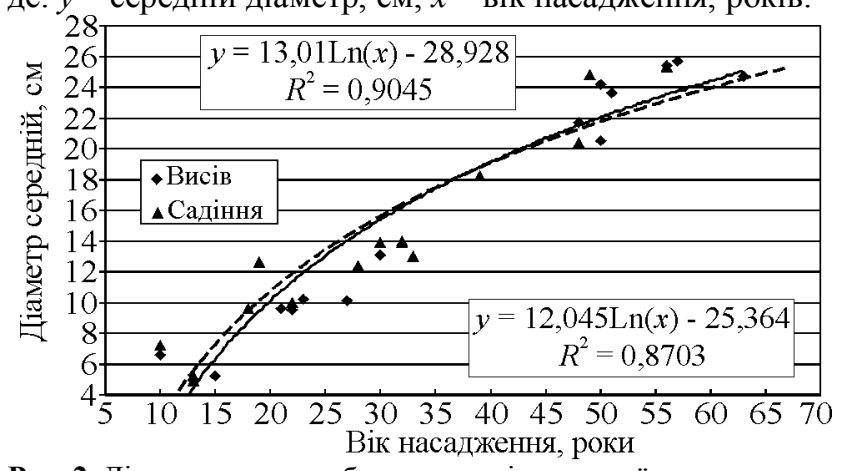

Рис. 2. Діаметри дерев дуба залежно від методу їхнього створення

Порівнюючи залежність діаметра дерев дуба від методу створення, виявлено, що до віку 35-40 років середні діаметри дерев дуба більші за умови створення культур садінням сіянців. Після цього віку значної розбіжності за діаметром дерев не виявлено.

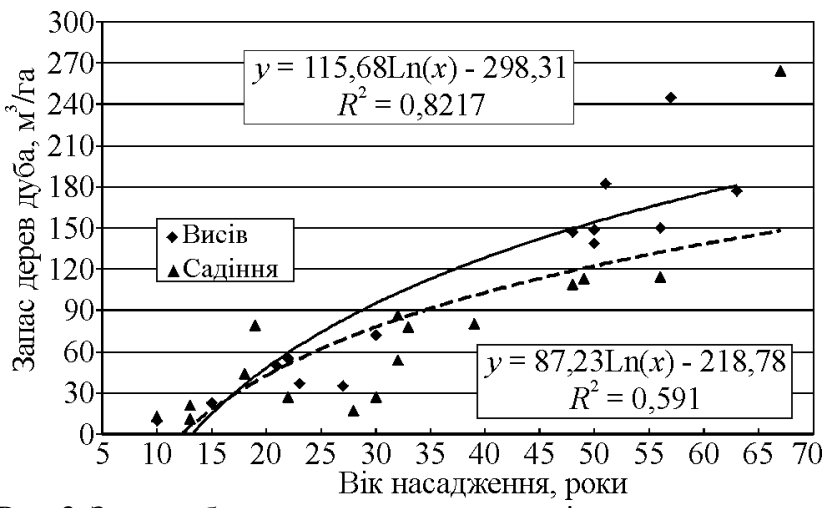

Рис. 3. Запас дуба в насадженнях залежно від методу їхнього створення

На відміну від середнього діаметра, на всіх досліджених пробних площах (рис. 3) виявлено різницю в запасах дуба за різних методів створення. Однак вагомої різниці між запасом 10-20-річних культур не встановлено. Зі збільшенням віку культур зростає різниця за запасом у насадженнях дуба, які створені висівом і садінням. Основним чинником, що впливає на запас дуба, 
вважаємо більшу середню висоту та більшу кількість збережених дерев.

Зміна запасу дерев дуба з віком штучних насаджень, створених висівом та садінням (формули (5) і (6)) свідчать про інтенсивніший ріст дубових насаджень, створених висівом жолудів. Також метод створення істотно впливає на їхню продуктивність:

$$
\begin{gathered}
y=115,68 \operatorname{Ln}(x)-298,31 ; \\
y=87,23 \operatorname{Ln}(x)-218,78,
\end{gathered}
$$

де: $y$ - запас, $\mathrm{m}^{3} \cdot \mathrm{ra}^{-1} ; x$ - вік насадження, років.

Дослідженнями виявлено, що середній запас дерев дуба у віці $10-68$ років становить $118 \mathrm{~m}^{3} \cdot \mathrm{ra}^{-1}$ за умови висівання жолудів і $71 \mathrm{~m}^{3} \cdot \mathrm{ra}^{-1}-$ за садіння сіянців, що на $48 \mathrm{~m}^{3} \cdot \mathrm{ra}^{-1}(39 \%)$ більше.

Порівнюючи загальну продуктивність змішаних дубових насаджень, встановлено, що вона також має логарифмічну залежність від методу створення культур (формули (7) і (8), рис. 4). На загальну продуктивність дубових насаджень впливає середня висота і діаметр дерев дуба, їхня збереженість у насадженні з віком і запас самих дерев дуба:

$$
\begin{aligned}
& y=172,49 \operatorname{Ln}(x)-427,48 \\
& y=148,9 \operatorname{Ln}(x)-361,25,
\end{aligned}
$$

де: $y$ - загальний запас насадження, $\mathrm{m}^{3} \cdot \mathrm{ra}^{-1} ; x$ - вік насадження, років.

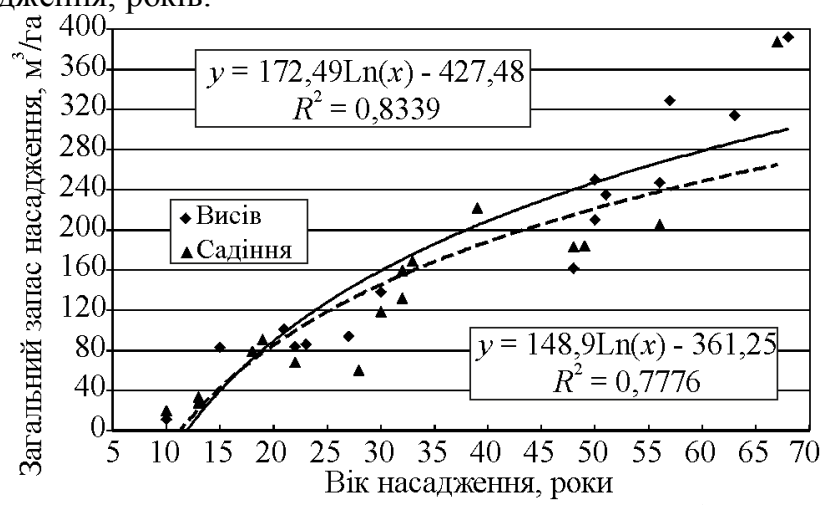

Рис. 4. Загальний запас дубових насаджень залежно від методу ї створення

Щодо загальної продуктивності дубових насаджень у досліджуваному віковому періоді, встановлено, що середній загальний запас насаджень становив $158 \mathrm{~m}^{3} \cdot \mathrm{ra}^{-}$ 1 за висівання культур і $131 \mathrm{~m}^{3} \cdot \mathrm{ra}^{-1}-$ за садіння, що на $27 \mathrm{~m}^{3} \cdot \mathrm{ra}^{-1}(17 \%)$ менше.

Висновки. За результатами дослідження 10-68-річних насаджень штучного походження встановлено, що метод їхнього створення істотно впливає на таксаційні показники, стан, якість, а в кінцевому результаті - на продуктивність дубових насаджень. Культури дуба, створені висівом, у II-VII класах віку мають на 6-19\% більшу середню висоту основного ярусу. Переважання за величиною середнього діаметра дубових насаджень, створених садінням, помітно до 35-40 років. У подальшому ця розбіжність вирівнюється і відхилення середніх діаметрів між культурами, що створені висівом жолудів і садінням сіянців, не виявлено. Запас дерев дуба істотно залежить від методу створення культур. Встановлено, що насадження, створені висівом, мають середній запас дерев дуба 118 , а створені садінням $71 \mathrm{~m}^{3} \cdot \mathrm{ra}^{-1}$, що на $39 \%$ менше. Середній запас дубових насаджень на 32 обстежених тимчасових пробних площах віком 10-68 роки становить $158 \mathrm{~m}^{3} \cdot \mathrm{ra}^{-1}$ за їхнього створення висівом і $131 \mathrm{~m}^{3} \cdot \mathrm{ra}^{-1}-$ за садіння сіянцями, що на $17 \%$ менше.
Отже, метод висіву жолудів під час створення насаджень із дуба звичайного на незарослих зрубах у свіжих грабових дібровах забезпечує збільшення поруч 3 іншими лісівничо-таксаційними показниками такого важливого показника, як їхня продуктивність, що $є$ надзвичайно актуальним для цілей сучасного лісогосподарського виробництва. Отже, притримуючись засад екологічно орієнтованого лісівництва, під час відтворення дубових насаджень на зрубах у свіжих грабових дібровах перевагу доцільно віддавати методу висіву жолудів на постійне місце їхнього зростання, що забезпечить створюваним насадженням, окрім інших критеріїв, високу продуктивність та біологічну стійкість.

\section{Перелік використаних джерел}

Bondar, A. O., \& Hordiienko, M. I. (2006). Formuvannia lisovykh nasadzhen $u$ dibrovakh Podillia [Formation of forest standss in oak forests of Podillia]. Kyiv : Urozhai. [in Ukrainian].

Borchert, M. I., \& Tyler, C. M. (2010). Acorn Dispersal of California Black Oak after a Stand-Replacing Fire. Fire Ecology, 6(3), 136141. https://doi.org/10.4996/fireecology.0603136

Brudvig, L. A., \& Asbjornsen, H. (2007). Stand structure, composition, and regeneration dynamics following removal of encroaching woody vegetation from Midwestern oak savannas. Forest Ecology and Management, 244(1-3), 112-121. https://doi.org/10.1016/i.foreco.2007.03.066

Clark, S. L., \& Schweitzerb, C. J. (2016). Stand dynamics of an oak woodland forest and effects of a restoration treatment on forest health. Forest Ecology and Management, 381, 258-267. https://doi.org/10.1016/j.foreco.2016.09.026

Dey, D. C., \& Kabrick, J. M. (2016). Restoration of Midwestern Oak Woodlands and Savannas. In J. A. Stanturf. Restoration of Boreal and Temperate Forests. CRC Press, Taylor \& Francis Group, Boca Raton, (pp. 401-428). London, New York.

Dey, D. C., Kabrick, J. M., \& Schweitzer, C. J. (2017). Silviculture to Restore Oak Savannas and Woodlands. Journal of Forestry, 115(3), 202-211. https://doi.org/10.5849/jof.15-152

Hensiruk, S. A. (2002). Optymizatsiia lisystosti - zaporuka pryzupynennia ekolohichnykh kataklizmiv [Optimization of forest cover - a key for the stopping of ecological cataclysms]. Scientific Bulletin of UNFU, 12(1), 82-90. [in Ukrainian].

Hordiienko, M. I., Hoichuk, A. F., \& Hordiienko, N. M. (1999). Shtuchni lisy $v$ dibrovakh [Artificial forests in oak forests]. Zhytomyr: Polissia. [in Ukrainian].

Hrom, M. M. (2002). Taksatsiia nasadzhen [Forest taxation]. Lviv: Ukr DLTU. [in Ukrainian].

Krinard, R., M., \& Johnson, R. L. (1988). Stand Parameters of a $27-$ Year-Old Water. Oak Stands on Old Field Loessial Soils. Res. Note SO-348. New Orleans, LA: U. S. Department of Agriculture, Forest Service, Southern Forest Experiment Station. https://doi.org/10.2737/SO-RN-348

Lohhinov, B. I. (1968). Sposoby zmishennia porid v lisovykh kulturakh Ukrainy [Ways of mixing of forest species in forest standss of Ukraine]. Pidvyshchennia produktyvnosti lisiv: zbirnyk naukovykh prats lisohospodarskoho fakultetu USKhA, 67-80. [in Ukrainian].

Lositskiy, K. B. (1963). Vosstanovlenie dubrav [Restoration of oak forests]. Moscow: Izdatelstvo selskohozyaystvennoy literaturyi, zhurnalov i plakatov. [in Russian].

Maiboroda, V. A. (2010). Stan dubovykh nasadzhen u lisovomu fondi Ukrainy ta perspektyvy yikh vidtvorennia [State of oak standss in the forest fund of Ukraine and perspectives for their reproduction]. Scientific Bulletin of UNFU, 20(12), 28-32. [in Ukrainian].

Morozov, G. F. (1950). Ocherki po lesokulturnomu delu [Essays on silviculture]. Moscow - Leningrad: Goslesbumizdat. [in Russian].

Rudnev, D. F., \& Ryibachok, P. A. (1975). Lesohozyaystvennyie meropriyatiya kak sposob povyisheniya ustoychivosti i proizvoditelnosti dubrav Ukrainyi [Forest management measures as a way of increasing the sustainability and productivity of oak forests of Ukraine]. Lesovedenie, 4, 44-51. [in Russian]. 
Shvidenko, A. Z., Strochinskiy, A. A., Savich, Yu. N., \& Kashpor, S N. (1987). Normativno-spravochnyie materialyi dlya taksatsii lesov Ukrainyi i Moldavii [Regulatory reference materials for forest taxation of Ukraine and Moldova]. Kyiv : Urozhai. [in Ukrainian].

Soldatov, A. G. (1961). Vyiraschivanie vyisokoproduktivnyih dubrav [Cultivation of highly productive oak forests]. Moscow: Selhozizdat. [in Russian].

Thompson, D. (2017). Research to policy: Enabling oak woodland restoration. California Agriculture, 71(1), 22-22. https://doi.org/10.3733/ca.2017a0003

Tihonov, S. T. (1970). Analiz rosta kultur duba, zalozhennyih posevom i posadkoyu [Analysis of growth of oak standss planted by sowing and planting]. Lesnoe hozyaystvo: sbornik nauchnyih trudov Tatarskoy lesnoy opyitnoy stantsii, 18, 12-14. [in Russian].

West, P. V. (2006). Growing Stands Forests. Springer-Verlag, Berlin, Hielderberg. https://doi.org/10.1007/3-540-32479-8

Yurkevich, I. D. (1960). Dubravyi Belorusskoy SSR i ih vosstanovlenie [Oak forests of Belorussian SSR and their restoration]. Minsk: AN BSSR. [in Belarus].

\title{
А. С. Остапчук'1, В. С. Кузевич², А. В. Соваков ${ }^{3}$
}

Уманский национальный университет садоводства, г. Умань, Украина ${ }^{2}$ ПП НУБиП Украины "Бережанский агротехнический институт", г. Бережаны, Украина ${ }^{3}$ Национальный университет биоресурсов и природопользования Украины, г. Киев, Украина

\section{ВЛИЯНИЕ МЕТОДА СОЗДАНИЯ НАСАЖДЕНИЙ ДУБА ОБЫКНОВЕННОГО ( QUERCUS ROBUR L.) НА ИХ ПРОИЗВОДИТЕЛЬНОСТЬ В УСЛОВИЯХ СВЕЖЕЙ ГРАБОВОЙ ДУБРАВЫ ПРАВОБЕРЕЖНОЙ ЛЕСОСТЕПИ УКРАИНЫ}

\begin{abstract}
Исследована производительность искусственных дубовых насаждений свежих грабовых дубрав в зависимости от метода их создания. По данным пробных площадей в возрасте 10-68 лет определены основные лесоводственно-таксационные показатели культур дуба обыкновенного (Quercus robur L.). Выявлены их зависимость от метода создания и различие в производительности культур, созданных посадкой сеянцев и посевом желудей на свежих срубах. Установлено, что, начиная с 10летнего возраста, и в дальнейшем, средние высоты дуба существенно зависят от метода создания культур. Высоты культур дуба, созданного посевом желудей, в возрасте молодняка на 6-9 \% больше, чем при создании культур посадкой сеянцев. Со временем эта разница увеличивается и в VII классе возраста разница по высоте составляет 11-19\%. Оценено влияние метода создания на средние диаметры деревьев дуба. Доказано, что до 40 лет средний диаметр модельных деревьев дуба больше при создании насаждения посадкой, но со временем диаметры выравниваются. Выявлена определенная последовательность в сохранении деревьев. После посева количество сохранившихся деревьев на 1 га в 10-летнем возрасте на 37,5 \% больше, но со временем разница уменьшается и в 68 лет составляет 17,3 \%. Установлено влияние метода создания на запас культур дуба. При создании культур посевом желудей, в зависимости от возраста насаждения, запас деревьев дуба на 1 га больше в среднем на $40 \%$. Установлено влияние метода создания культур на общую производительность смешанных дубовых древостоев. Определено, что при создании культур методом посева, запасы насаждений на 1 га больше в среднем на $17 \%$. Культуры дуба, созданные посевом, имеет лучшую очистку стволов от веток и сучьев, стволы более полнодревесные.
\end{abstract}

Ключевые слова: культуры дуба; состав насаждения; таксационные показатели; посев желудей; посадка сеянцев.

O. S. Ostapchuk', V. S. Kuzovych ${ }^{2}$, O. V. Sovakov ${ }^{3}$

${ }^{1}$ Uman National University of Horticulture, Uman, Ukraine ${ }^{2}$ Berezhany Agrotechnical Institute of National University of Life and Environmental Sciences of Ukraine, Berezhany, Ukraine ${ }^{3}$ National University of Life and Environmental Sciences of Ukraine, Kyiv, Ukraine

\section{INFLUENCE OF THE METHOD OF OAK (QUERCUS ROBUR L.) STANDS FORMATION ON THEIR PRODUCTIVITY UNDER THE CONDITIONS OF HORNBEAM-OAK FOREST IN THE FOREST-STEPPE ZONE OF RIGHT-BANK UKRAINE}

The methods of creation forest stands are the sets of techniques for the formation of artificial stands, the main of which are sowing and planting. The purpose of the research is determined by the definition of the productivity of artificial oak stands in the D2 condition of oak forest according to the method of their creation. The task of the study was to establish a number of test areas and determine the silvicultural and forest stands parameters of uneven-aged oak stands at the age of 10-68 years which were created by the method of planting the seedlings and sowing the acorn in areas of fresh logging areas. General laboratory selection of forest stands and their review in nature was conducted during the research. The establishment of test areas and the determination of forest stands parameters were carried out in accordance with generally accepted methods in forestry mensuration and forestry. It was determined that in stands created by sowing oak acorns in all classes of age the oak seedlings had a higher height. It was found out that the oak trees are cleaned from knots and branches, have more full-tree trunks. Oak stands created by sowing in the II - VII age classes have 6-19\% higher average height of the main stand. Comparing the dependence of the diameter of oak trees to the method of creation, we found that till the age of 35-40 the average diameter of oak trees was bigger than in the stands created by planting seedlings. There is no significant divergence in the diameter after this age. Unlike the average diameter, the difference in oak stock volumes under different methods of creation is found on all studied areas. Meanwhile, there is no significant difference between stock volumes of 10-20-year-old stands. With the increase of the age of stands, the difference in stock volume between oak stands created by sowing acorns and planting seedling increases. The research determined that the average stock volume of oak trees at the age of 10-68 years was $118 \mathrm{~m}^{3} \cdot \mathrm{ha}^{-1}$ under the condition of sowing acorns and $71 \mathrm{~m}^{3} \cdot \mathrm{ha}^{-}$ ${ }^{1}$ - of planting seedlings, which is $48 \mathrm{~m}^{3} \cdot \mathrm{ha}^{-1}(39 \%)$ less. Regarding the overall productivity of oak stands, it was found that the average total stock volume of stands was $158 \mathrm{~m}^{3} \cdot \mathrm{ha}^{-1}$ when sowing acorns and $131 \mathrm{~m}^{3} \cdot \mathrm{ha}^{-1}$ when planting seedlings which is $27 \mathrm{~m}^{3} \cdot \mathrm{ha} \mathrm{a}^{-1}$ less $(17 \%)$. By means of the study of 10-68-year-old artificial stands it was found that the method of creation significantly influences the forest stands parameters, condition, quality and, ultimately, the productivity of oak stands. The change of the average diameter by age of oak stands, depending on the method of creation, makes it possible to argue that in the oak stands at the age of 10-68 years the differences in tree diameter were not detected and the method of creation does not affect this forest stands parameters. The age-related change in the volume stock of oak trees planted by sowing acorns and planting seedlings indicates on more intense growth of oak stands created by sowing acorns. Comparing the overall productivity of mixed oak stands, it is determined that it has a logarithmic dependence on the method of creating stands. The overall productivity of oak stands is influenced by the average height and diameter of the oak trees, their conservation in the stand, the stock volume of the oak trees. Based on the principles of ecologically oriented forestry in fresh hornbeam oak forests on bare logging areas, we recommend creating young forests by sowing acorns.

Keywords: oak; stand composition; taxation indicators; acorns sowing; seedling planting. 